\title{
Rapid tranquilization for agitated patients in emergency psychiatric rooms: a randomized trial of olanzapine, ziprasidone, haloperidol plus promethazine, haloperidol plus midazolam and haloperidol alone
}

\author{
Tranquilização rápida para pacientes agitados nos serviços \\ de emergência psiquiátrica: um ensaio clínico randomisado \\ de olanzapina, ziprasidona, haloperidol mais prometazina, \\ haloperidol mais midazolam e haloperidol em monoterapia
}

\author{
Leonardo Baldaçara, ${ }^{1,2}$ Marsal Sanches, ${ }^{3,4}$ Daniel Cruz Cordeiro, ${ }^{3}$ Andrea Parolin Jackowski² \\ ${ }^{1}$ Universidade Federal do Tocantins (UFT), Palmas, TO, Brazil \\ 2 Universidade Federal de São Paulo (UNIFESP), São Paulo, SP, Brazil \\ ${ }^{3}$ Irmandade da Santa Casa de Misericórdia de São Paulo, São Paulo, SP, Brazil \\ ${ }^{4}$ University of Texas, Austin, Texas, USA
}

\begin{abstract}
Objective: To compare the effectiveness of intramuscular olanzapine, ziprasidone, haloperidol plus promethazine, haloperidol plus midazolam and haloperidol alone as the first medication(s) used to treat patients with agitation and aggressive behavior. Method: One hundred fifty patients with agitation caused by psychotic or bipolar disorder were randomly assigned under double-blind conditions to receive olanzapine, ziprasidone, haloperidol plus midazolam, haloperidol plus promethazine or haloperidol alone. The Overt Agitation Severity Scale, Overt Aggression Scale and Ramsay Sedation Scale were applied within 12 hours after the first dosage. Results: All medications produced a calming effect within one hour of administration, but only olanzapine and haloperidol reduced agitation by less than 10 points, and only olanzapine reduced aggression by less than four points in the first hour. After twelve hours, only patients treated with haloperidol plus midazolam had high levels of agitation and aggression and also more side effects. Ziprasidone, olanzapine and haloperidol alone had more stable results for agitation control, while ziprasidone, haloperidol plus promethazine and olanzapine had stable results for aggression control. Conclusion: Olanzapine, ziprasidone, haloperidol plus promethazine, haloperidol plus midazolam and haloperidol were effective in controlling agitation and aggression caused by mental illness over 12 hours. Although all the drugs had advantages and disadvantages, haloperidol plus midazolam was associated with the worst results in all the observed parameters.
\end{abstract}

Descriptors: Psychomotor agitation; Psychotic disorders; Antipsychotic agents; Emergencies; Tranquilizing agents/adverse effects

\section{Resumo}

Objetivo: Comparar a eficácia da olanzapina, ziprasidona, haloperidol associado ao midazolam, haloperidol associado à prometazina e haloperidol isoladamente por via intramuscular como primeira escolha no tratamento de pacientes em agitação e agressividade. Método: Cento e cinquenta pacientes com agitação psicomotora por transtorno psicótico ou transtorno bipolar foram recrutados para estudo duplo-cego e receberam olanzapina, ziprasidona, haloperidol associado a midazolam, haloperidol associado a prometazina ou haloperidol isoladamente. Foram aplicadas as escalas Overt Agitation Severity Scale, Overt Aggression Scale $e$ Ramsay Sedation Scale no periodo de 12 horas após a primeira aplicação. Resultados: Todas as medicaçōes foram capazes de acalmar os pacientes após uma hora da administração. Apenas a olanzapina e o haloperidol reduziram a agitação para menos de 10 pontos e apenas a olanzapina reduziu a agressividade para menos de quatro pontos nesse periodo. Doze horas depois, apenas o haloperidol com midazolam apresentou valores altos para a agitação e agressividade, e também esteve relacionado com maior proporção de efeitos colaterais. A ziprasidona, a olanzapina e o haloperidol apresentaram resultados mais estáveis para o controle da agitação e a ziprasidona, haloperidol associado a prometazina e olanzapina para o controle da agressividade. Conclusáo: A olanzapina, a ziprasidona, o haloperidol associado a prometazina, o haloperidol associado ao midazolam e o haloperidol isoladamente foram efetivos no controle da agitação e da agressividade secundária a transtornos mentais dentro de 12 horas. Todas as drogas apresentaram vantagens e desvantagens, exceto pela associação haloperidol e midazolam que demonstrou os piores resultados em todos os parâmetros.

Descritores: Agitaçāo psicomotora; Transtornos psicóticos; Agentes antipsicóticos; Emergências; Tranquilizantes/efeitos adversos

Correspondence Leonardo Baldaçara

Universidade Federal do Tocantins - CUP - Medicina Av. NS 15 ALC NO 14, 109 Norte - Caixa Postal 114

77001-090 Palmas, TO, Brazil

Phone/Fax: (+55 63) 3232-8158

Email: leonardobaldassara@gmail.com 


\section{Introduction}

Agitated or violent behavior primarily results from serious mental illness and substance misuse, ${ }^{1,2}$ and constitutes approximately $10 \%$ of the use of emergency services. ${ }^{2,3}$ Because rates of mental illness are similar worldwide, ${ }^{2-4}$ the management of aggressive and violent behavior is an important issue and a mental health priority in low and middle income countries, where the majority of the world's population live, and particularly in countries with large populations ${ }^{2}$ such as Brazil.

Drugs commonly used to manage agitation and violence in emergency situations include antipsychotics, benzodiazepines and combinations of antipsychotics and benzodiazepine or antipsychotics and promethazine. ${ }^{5,6}$ More recent strategies include longer-acting drugs, such as zuclopenthixol acetate, ${ }^{7}$ and rapidly acting intramuscular formulations of the atypical antipsychotics olanzapine ${ }^{8}$ and ziprasidone. ${ }^{9}$ Guidelines state that drugs used in such situations should calm patients safely and rapidly without excessive sedation (rapid tranquilization). However, the guidelines differ regarding which drugs to use. ${ }^{4,10}$ In this context, some of the new generation antipsychotics are not only for oral use, but can also be used parenterally, which represents an advance in the rapid management of acute behavioral alterations. Additionally, knowledge regarding antipsychotic profiles in the treatment of agitation and aggressive behavior is limited, and few studies have compared the effects of different drugs in rapid tranquilization.

We conducted a double-blind controlled trial to compare the effectiveness of intramuscular olanzapine, ziprasidone, haloperidol plus promethazine, haloperidol-plus- midazolam and haloperidol alone as the first medication(s) used to treat patients with agitation caused by psychosis.

\section{Method}

\section{Randomization}

The method of randomization employed in this clinical trial was allocation by permuted blocks. Each drug regimen was assigned to blocks of five patients and distributed in this order: olanzapine, ziprasidone, haloperidol plus prometazine, haloperidol plus midazolam and haloperidol. This assignment was repeated until the total number of subjects (150) was reached.

\section{Participants}

One hundred fifty subjects who had been admitted to the Psychiatric Emergency Room of Santa Casa de São Paulo in Brazil were selected. The inclusion criteria were as follows: signs of agitation, age between 18 and 50 years, bipolar (maniac or mixed episode) or psychotic disorder diagnosis (DSM-IV-TR criteria), Overt Agitation Severity Scale Total Score (OASS) equal or greater than 20 and an Overt Aggressive Scale (OAS) with four or more positive items. The exclusion criteria were as follows: disorders due to drug abuse, organic disorder, anxiety or personality disorder (DSM-IV-TR criteria), failure to agree to participate in the study, incapability of completing all steps and unstable clinical disease.

Upon entry of each patient into the study, demographic information, medical history, characteristics of the current symptomatology and psychiatric and family history were obtained. In addition, a full physical and neurological examination was completed as soon as possible, although only if the patient was considered eligible for the study.

All participants provided written informed consent before and after participating in this study, which was reviewed and approved by the institutional review board. Written consent was obtained before admission to the emergency unit by a legal guardian and after 12 hours by the patient (when he or she was able to understand the information) or by the guardian. This study was conducted according to the principles of the Declaration of Helsinki and Good Clinical Practice. It was approved by the Institutional Review Board (IRB) of Santa Casa de São Paulo (Project CEP 364/07) and was registered in the Australian New Zealand Clinical Trials Registry as number ACTRN12610000033044. The international registration is available at http://www.anzctr. org.au/trial_view.aspx?ID=334977.

\section{Study design and assessment instruments}

To evaluate inter-rater reproducibility, two raters repeatedly applied OASS, OAS and RSS to the patients admitted to the emergency room before the study until the intraclass correlation coefficient (ICC) was greater than 0.80 . After 10 applications, the ICC was 0.90 .

The study medications were packaged in identical color-coded boxes. The first dosage included either $10 \mathrm{mg}$ of olanzapine, $20 \mathrm{mg}$ of ziprasidone, $5 \mathrm{mg}$ of haloperidol plus $50 \mathrm{mg}$ of prometazine or $5 \mathrm{mg}$ of haloperidol plus $15 \mathrm{mg}$ of midazolam. Dosages were chosen based on previous studies. ${ }^{2,10-12}$ After the initial dose, only additional doses of the haloperidol and promethazine combination could be used, according to clinician judgment. If a subject needed another intervention, he or she was immediately removed from the study.

All subjects were assessed 1 hour, 2 hours, 4 hours, 6 hours and 12 hours after the first administration of the medication. Protocoldefined psychiatric assessments included the OASS, the number of positive items on the OAS and the Ramsay Sedation Scale score (RSS). No additional medications or side effects were observed.

Patients were assessed by two psychiatrists. The psychiatrists were all masked with regard to the patient's treatment assignment, and patients were instructed not to reveal their current treatment to the investigators. In an attempt to reduce inter-rater variability, all raters were trained to administer the psychometric tools according to common standards prior to study enrollment. In addition, psychopathology rater training was performed regularly throughout the study to establish a high inter-rater reliability. Finally, all of the investigators conducted joint interviews before the commencement of the study, and joint ratings were made throughout the study to check inter-investigator agreement.

The clinical safety of treatment was assessed by spontaneous notification and an open-ended inquiry into adverse events as well as a full physical examination and measurement of vital signs at each visit. Adverse events and drug compliance were carefully monitored throughout the study. Patients were withdrawn 
from the trial if they requested discontinuation, if the physician suggested withdrawal because of an adverse event, if the treatment showed lack of efficacy or if the patients were uncooperative.

\section{Statistical analyses}

All 150 participants completed the acute trial. Data were analyzed using the Statistical Package for the Social Sciences 15.0 for Windows. ${ }^{13} \mathrm{~A}$ two-tailed statistical significance level was set at $\mathrm{p}<0.05$. Skewness and kurtosis were used as normality tests.

In this study, numerical values are presented as the mean and standard deviation (SD) unless otherwise specified. Group comparisons of baseline demographic and clinical characteristics were assessed via the one-way analysis of variance (ANOVA) when variable was normally-distributted, Kruskal-wallis test when variable was not normally-distributted and chi-square test for categorical variables.

The outcome evaluation used mixed-effect analyses of covariance (ANCOVAs) with medication (olanzapine, ziprasidone, haloperidol plus midazolam, haloperidol plus promethazine and haloperidol alone) as a between-groups factor and time (1 hour, 2 hours, 4 hours, 6 hours and 12 hours) as a within-group factor. OASS at time zero, OAS at time zero, the number of additional medications and the presence of excessive sedation were fixed covariates, and symptom ratings (OASS, OAS and RSS) were time-varying covariates. The analyses were based on mean score differences between the groups at each time point. Analyses of variance with post-hoc Duncan's tests were calculated to compare the mean OASS, OAS and RSS scores between the groups. Effect size was evaluated by the mean ratio calculated with OASS and OAS after 1, 2, 4, 6 and 12 hours as the numerators, and OASS and OAS at time zero as the denominator. The mean ratio represents the proportion of score reductions compared to the initial scores. The mean of all ratios was used as the parameter representing a stable result because lower values represent minor variations, i.e., lower rates of recurrence of agitation or aggression within 12 hours.

\section{Results}

A total of 163 patients were screened, and 150 underwent randomization and received at least one dose of medication (Figure 1). Eighty-eight did not meet the inclusion criteria, and five refused to participate.

For the total patient group, the average mean age was 32.1 $(\mathrm{SD}=7.7), 59.5 \%$ were men, $60.6 \%$ had a psychotic disorder and $39.4 \%$ had bipolar disorder. At the time of entry into the study, the patients had an OASS (mean) of $30.8(\mathrm{SD}=5.1)$ and an OAS of $10.1(\mathrm{SD}=2.5)$. The sociodemographic and clinical characteristics of all five treatment groups were similar (Table 1). No statistically significant differences with respect to age, gender, education, employment and diagnosis were found between the four medication groups.

When a patient displayed agitation and/or aggressive behavior within 12 hours, additional medication was administered when a verbal approach failed. If the behavior was at high risk, mechanical restriction was performed. A larger proportion of patients who received haloperidol plus midazolam (70\%) required mechanical restraint between one hour after the first medication and the final 12 hours of observation, followed by the groups receiving ziprasidone (33\%), haloperidol alone (20\%), haloperidol plus promethazine $(17 \%)$ and olanzapine $(3 \%)(\mathrm{p}<0.001)$. The haloperidol plus midazolam group had a higher mean value of additional medication after first the dosage $(1.73 ; \mathrm{SD}=0.87)$, followed by the haloperidol alone group $(1.53 ; \mathrm{SD}=1.19)$ and the haloperidol plus promethazine group $(1.10 ; S D=1.03)$; $\mathrm{p}<0.001$. The groups receiving ziprasidone $(0.77 ; \mathrm{SD}=0.98)$ and olanzapine $(0.37 ; \mathrm{SD}=0.77)$ had a mean value less than 1 , which indicates that a higher number of patients did not need additional medications.

Side effects were higher in the haloperidol plus midazolam (50\%), haloperidol alone (38\%), and haloperidol plus promethazine (33\%) groups, but these differences were not statistically significant. Excessive sedation was the main side effect ( $70 \%$ of all side effects) and was highest in the haloperidol plus midazolam group ( $<0.001)$. Extrapyramidal side effects were present in only three patients in the haloperidol plus midazolam group, five patients in the haloperidol plus promethazine group and five patients in the haloperidol alone group (not statistically significant). Hypotension was present in one patient in the olanzapine group, six patients in the ziprasidone group, five patients in the haloperidol plus midazolam group and three in the haloperidol plus promethazine group.

Table 2 describes the treatment outcomes in the five treatment groups. The OASS, OAS (number of positive items) and the RSS mean total scores were compared at each time point by ANCOVA (including time zero for the OASS and OAS) covarying for mechanical restriction after the first dosage and the number of additional medications. The timexdrug interactions, indicating differences in the effectiveness among treatments, were significant. For more details, see Figure 2.

The OASS mean total scores at the first hour were, in decreasing order, 14.6 ( $\mathrm{SD}=3.4)$ for the haloperidol plus midazolam group, 13.0 ( $\mathrm{SD}=5.3)$ for the haloperidol plus promethazine group, $12.6(\mathrm{SD}=4.3)$ for the ziprasidone group, $4.9(\mathrm{SD}=2.1)$ for the haloperidol alone group and $2.9(\mathrm{SD}=0.9)$ for the olanzapine group ( $\mathrm{p}<0.001$ ). The OAS total score at the first hour was highest for the haloperidol plus promethazine group (8.8; $\mathrm{SD}=4.6$ ), followed by the haloperidol plus midazolam (5.5; $\mathrm{SD}=2.9$ ), haloperidol alone ( $4.3 ; \mathrm{SD}=1.0$ ), ziprasidone ( $4.3 ; \mathrm{SD}=$ $1.9)$ and olanzapine groups $(3.4 ; \mathrm{SD}=1.0)(\mathrm{p}<0.001)$. The RSS at the first hour was highest for the haloperidol plus midazolam group (3.0; $\mathrm{SD}=1.1)$ and was similar for the other groups $(\mathrm{p}=0.016)$.

In the middle of the acute treatment (second, fourth and sixth hours), significant group improvements were observed in all groups. Moreover, differences between them were observed only for the OASS for all times. Differences in the OAS were present only in the second hour, and there were no RSS differences between groups.

At the endpoint (twelfth hour), the OASS was highest for the haloperidol plus midazolam group (12.6; $\mathrm{SD}=2.9)$, followed by 


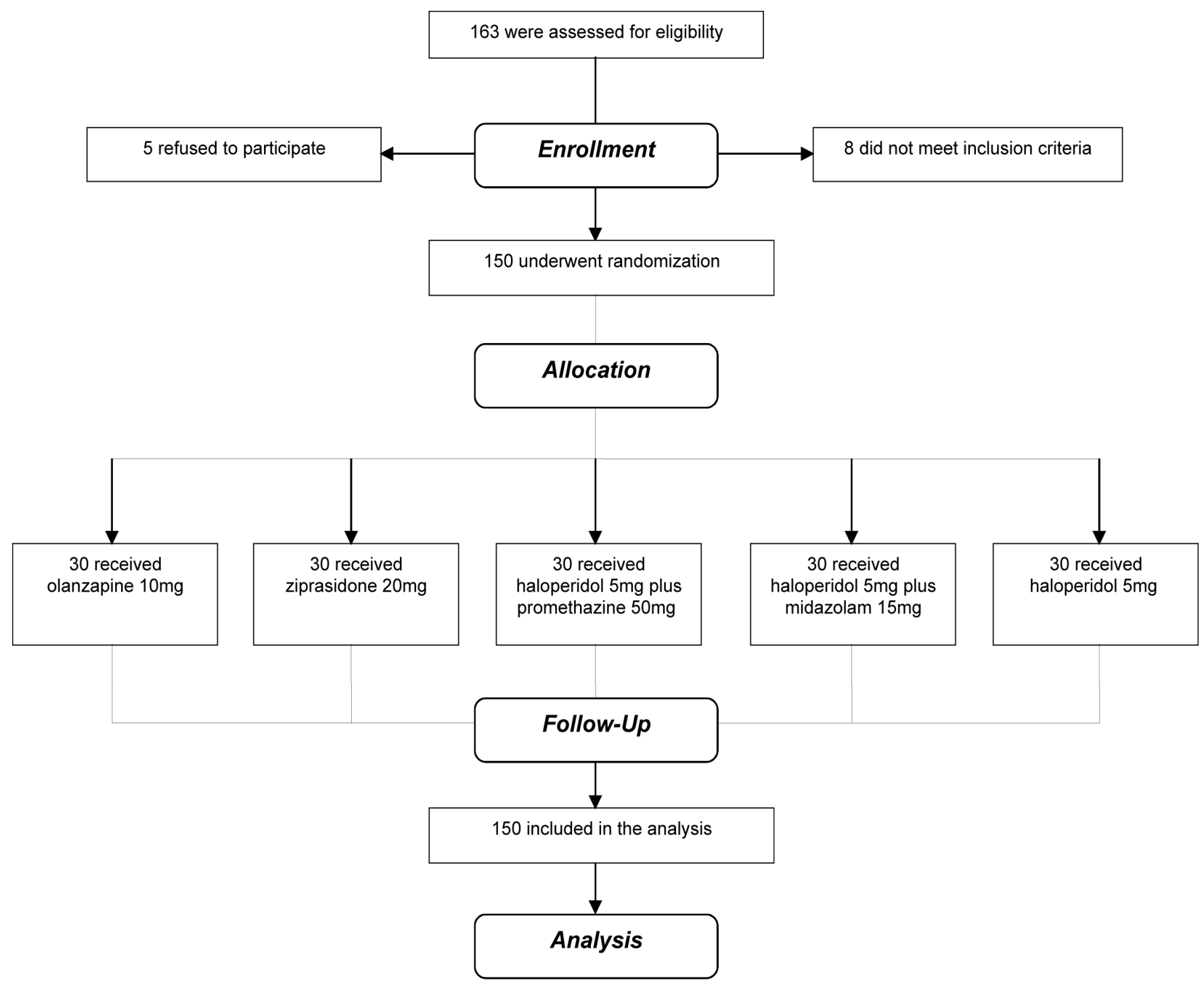

Figure 1 - Enrollment and randomization

the ziprasione (4.1; $\mathrm{SD}=1.0)$, haloperidol plus promethazine (2.2; $\mathrm{SD}=0.7)$, haloperidol $(1.4 ; \mathrm{SD}=0.1)$ and olanzapine groups $(0.5$; $\mathrm{SD}=0.2),(\mathrm{p}=0.001)$. For OAS, the highest mean total score was found in the haloperidol plus midazolam group (4.5; SD =1.9), and the lowest mean value was for the haloperidol plus promethazine group $(0.8 ; \mathrm{SD}=0.3)$. The olanzapine $(2.8 ; \mathrm{SD}=0.5)$, haloperidol (2.6; $\mathrm{SD}=0.2)$ and ziprasidone $(2.4 ; \mathrm{SD}=0.3) \mathrm{OAS}$ means were similar $(\mathrm{p}<0.001)$. There were no differences in RSS at the twelfth hour.

To compare effect sizes, we calculated the mean ratios for the OASS and OAS between each hour (1, 2, 4, 6 and 12 hours after) and time zero. For the OASS, ziprasidone and olanzapine produced lower scores, indicating more improvement in agitation and stable results. Haloperidol had good results, while haloperidol plus promethazine and haloperidol plus midazolam had the worst results. According to the Waller-Duncan post-hoc test (5\%), ziprasidone was similar to olanzapine and haloperidol, and all three had lower scores than haloperidol plus midazolam and haloperidol plus promethazine (olanzapine $=$ ziprasidone $=$ haloperidol $<$ haloperidol plus promethazine $=$ haloperidol plus midazolam). For the OAS, ziprasidone had the best results, followed by haloperidol plus promethazine, olanzapine, haloperidol alone and haloperidol plus midazolam. The Waller-Duncan test demonstrated that ziprasidone $=$ haloperidol plus promethazine $<$ olanzapine $<$ haloperidol $=$ haloperidol plus midazolam.

\section{Discussion}

The intramuscular antipsychotics tested in this research were effective in the rapid tranquilization of patients exhibiting agitation or violence as a result of mental illness. However, important differences were found in the effects of the interventions.

Consensus guidelines emphasize that calming, rather than oversedating, the patient is a key goal in the initial management of agitation in the acute setting. ${ }^{14-16}$ Historically, traditional agents have been used as first-line medications for the treatment of acutely agitated patients, in part because of the availability of parenteral preparations. However, because of the recent introduction of parenteral forms of atypical 
Table 1 - Demographic and clinical characteristics of the study population

\begin{tabular}{|c|c|c|c|c|c|c|c|}
\hline Variable & Olanzapine & Ziprasidone & $\begin{array}{c}\text { Haloperidol } \\
\text { plus } \\
\text { midazolam }\end{array}$ & $\begin{array}{c}\text { Haloperidol } \\
\text { plus } \\
\text { promethazine }\end{array}$ & $\begin{array}{c}\text { Haloperidol } \\
\text { alone }\end{array}$ & $\mathbf{F} / \chi^{2}$ & $p$ \\
\hline Gender, male/female, $N$ & $18 / 12$ & $16 / 14$ & $18 / 12$ & $19 / 11$ & $20 / 10$ & $1.229^{*}$ & 0.873 \\
\hline Age, mean (SD), y & $30.37(9.01)$ & $33.13(6.36)$ & $32.00(7.18)$ & $34.57(9.31)$ & $31.13(5.17)$ & 1.790 & 0.134 \\
\hline Education level, mean (SD), y & $7.02(2.32)$ & $7.12(3.34)$ & $7.35(4.22)$ & $7.65(2.45)$ & $7.33(3.40)$ & 1.208 & 0.845 \\
\hline Unemployed (\%) & 52 & 45 & 53 & 48 & 46 & 17.929 & 0.118 \\
\hline \multicolumn{8}{|l|}{ DSM IV-TR diagnoses, N (\%) } \\
\hline Psychotic disorder & $18(60)$ & $20(61)$ & $16(53)$ & $17(57)$ & $17(57)$ & 1.265 & 0.867 \\
\hline Bipolar I disorder & $12(40)$ & $10(33)$ & $14(47)$ & $13(43)$ & $13(43)$ & - & - \\
\hline Mechanical restriction, $\mathrm{N}(\%)$ & $1(3)$ & $10(33)$ & $21(70)$ & $5(17)$ & $6(20)$ & 41.204 & $<0.001$ \\
\hline Repetition, mean (SD), $\mathrm{N}$ & $0.37(0.77)$ & $0.77(0.98)$ & $1.73(0.87)$ & $1.10(1.03)$ & $1.53(1.19)$ & $35.148^{* *}$ & $<0.001$ \\
\hline Excessive sedation, $\mathrm{N}(\%)$ & $1(3)$ & $3(10)$ & $12(40)$ & $1(3)$ & $3(10)$ & 24.231 & $<0.001$ \\
\hline Side effects, mean (SD), $N$ & $5(17)$ & $8(27)$ & $15(50)$ & $10(33)$ & $11(38)$ & 7.837 & 0.098 \\
\hline OASS at time zero, mean (SD) & $29.6(4.3)$ & $32.3(4.6)$ & $31.6(4.9)$ & $33.3(4.3)$ & $27.4(5.6)$ & 7.231 & $<0.001$ \\
\hline OAS at time zero, mean (SD) & $9.5(2.1)$ & $10.5(2.4)$ & $10.7(2.3)$ & $11.1(2.5)$ & $9.0(2.5)$ & 4.093 & 0.004 \\
\hline
\end{tabular}

$S D=$ Standard Deviation; DSM-IV-TR = Diagnostic and Statistical Manual of Mental Disorders - Text Revision; OASS = Overt Agitation Severity Scale; $O A S=$ Overt Agitation Scale.

${ }^{*}$ Chi-square test; ${ }^{* *}$ Kruskal-wallis test.

antipsychotics, such as olanzapine and ziprasidone, these medications have been gaining popularity as first-line treatment options because of their more favorable side effect profiles. ${ }^{14,17}$

Haloperidol is a highly potent, widely used neuroleptic that may promote adequate levels of tranquilization when administered intramuscularly (IM). Acute adverse effects include akathisia, dystonic reactions and neuroleptic malignant syndrome. ${ }^{17}$ Despite these adverse effects, which may occur even after a single injection, haloperidol is the preferred treatment, is widely available and is used in emergency situations. ${ }^{17}$

Butyrophenones belong to a class of drugs that have been available for many years. Haloperidol reaches peak plasma levels about 20 minutes after intramuscular administration. The mean plasma (terminal elimination) half-life has been determined to be $20.7(\mathrm{SD}=4.6$ ) hours, and although excretion begins rapidly, only 24 to $60 \%$ of the ingested radioactive drug is excreted (mainly as metabolites in urine, some in feces) by the end of the first week, and very small but detectable levels of radioactivity persist in the blood and are excreted for several weeks after dosing. About 1\% of the ingested dose is recovered unchanged in the urine.

Haloperidol alone reduces agitation and psychotic effects, as measured via different scales. ${ }^{18}$ In this study, haloperidol alone reduced agitation and aggression at the first hour, similar to atypical antipsychotics, and had stable results for agitation control but worse results for aggressive behavior control. In clinical practice, haloperidol alone has been used because it has fewer side effects (especially excessive sedation and hypotension ${ }^{19}$ ), but this option could be related to additional medication that was demand within 12 hours after the first administration. Moreover, haloperidol alone is associated with more extrapyramidal side effects, such as acute dystonia. ${ }^{4}$

However, haloperidol associated with other medications can produce superior results. ${ }^{18,20}$ Possible combinations that have been tested include haloperidol paired with lorazepam, ${ }^{21}$ thiothixene, ${ }^{20}$ phenobarbital ${ }^{20}$ and promethazine. ${ }^{22}$ Promethazine is an antihistamine that is combined with haloperidol in an IM injection for the management of acutely disturbed people. ${ }^{23}$ The rationale for this combination lies in the main sedative effects of promethazine and its antimuscarinic properties. ${ }^{23}$ The main adverse reactions of promethazine are gastrointestinal disturbances, dry mouth and blurred vision. Paradoxical reactions, such as central nervous system stimulation and extrapyramidal symptoms, have also been reported. ${ }^{23}$

In this study, we observed that haloperidol plus promethazine had higher scores of OASS and OAS in the first hour than all other medications. However, the patients who received this drug option likely had more serious behaviors in the early hours. When we observed effect size by the mean of all ratios, haloperidol plus promethazine had the worst results for agitation control, but better results for aggressive behavior control. In addition, the group receiving haloperidol plus promethazine had less need for additional medication, fewer side effects and less need of mechanical restriction than those receiving haloperidol alone and haloperidol plus midazolam.

Huf et al. showed that patients allocated haloperidol plus promethazine were more likely to be tranquil or asleep within 20 minutes than those who received intramuscular haloperidol alone and needed fewer additional medications, but no differences were found after 20 minutes. ${ }^{11}$ Haloperidol given without promethazine in this situation causes frequent serious adverse effects. ${ }^{24}$ Compared to midazolam used alone, haloperidol plus promethazine was an effective means of tranquilization, with over two-thirds of patients being tranquil or sedated by 30 minutes. Midazolam was more rapid but was associated with oversedation. ${ }^{2,24}$ Compared with lorazepam, more patients were tranquil or sedated within 30 minutes if given the combination treatment. ${ }^{25}$

The combination of IM benzodiazepines and haloperidol has historically been the standard of care for acute agitation in 
Table 2 - Changes in outcome measures during the study

\begin{tabular}{|c|c|c|c|c|c|c|c|c|}
\hline \multirow[t]{2}{*}{ Variable } & \multirow{2}{*}{$\begin{array}{l}\text { Olanzapine } \\
\text { Mean (SD) } \\
\end{array}$} & \multirow{2}{*}{$\begin{array}{l}\text { Ziprasidone } \\
\text { Mean (SD) }\end{array}$} & \multirow{2}{*}{$\begin{array}{c}\text { Haloperidol } \\
\text { plus } \\
\text { Midazolam }\end{array}$} & \multirow{2}{*}{$\begin{array}{c}\begin{array}{c}\text { Haloperidol } \\
\text { plus } \\
\text { Promethazine }\end{array} \\
\text { Mean (SD) } \\
\end{array}$} & \multirow{2}{*}{$\begin{array}{c}\begin{array}{c}\text { Haloperidol } \\
\text { alone }\end{array} \\
\text { Mean (SD) }\end{array}$} & \multirow[b]{2}{*}{$\mathbf{F}$} & \multirow[b]{2}{*}{$\mathbf{p}$} & \multirow[b]{2}{*}{ Duncan test $(5 \%)$} \\
\hline & & & & & & & & \\
\hline \multicolumn{9}{|l|}{ OASS } \\
\hline 1 hour & $2.9(0.9)$ & $12.6(4.3)$ & $13.4(3.4)$ & $29.4(7.6)$ & $4.9(2.1)$ & 25.348 & $<0.001$ & $4,3>2>5,1$ \\
\hline 2 hours & $2.1(1.2)$ & $10.2(6.8)$ & $13.0(1.6)$ & $15.7(2.4)$ & $6.3(1.4)$ & 8.967 & $<0.001$ & $4,3>2>5,1$ \\
\hline 4 hours & $1.2(0.5)$ & $5.8(2.0)$ & $6.9(2.7)$ & $5.2(1.4)$ & $1.4(0.5)$ & 3.503 & 0.009 & $3>2,4>5,1$ \\
\hline 6 hours & $1.2(0.4)$ & $5.0(2.0)$ & $5.1(2.4)$ & $4.0(1.3)$ & $1.4(0.1)$ & 5.291 & 0.001 & $3>2>4>5,1$ \\
\hline 12 hours & $0.5(0.2)$ & $4.1(1.0)$ & $12.6(2.9)$ & $2.2(0.7)$ & $1.4(0.1)$ & 17.043 & 0.001 & $3>2>4>5,1$ \\
\hline \multicolumn{9}{|l|}{ OAS } \\
\hline 1 hour & $3.4(1.0)$ & $4.3(1.0)$ & $5.5(2.9)$ & $8.8(4.6)$ & $4.3(1.9)$ & 11.571 & $<0.001$ & $4>3>2,5>1$ \\
\hline 2 hours & $2.8(0.5)$ & $2.6(0.9)$ & $5.7(4.4)$ & $4.0(2.2)$ & $3.3(2.5)$ & 5.439 & $<0.001$ & $3>1,2,4,5$ \\
\hline 4 hours & $2.8(0.5)$ & $2.6(0.9)$ & $3.0(1.6)$ & $2.3(0.1)$ & $2.9(0.3)$ & 0.330 & 0.857 & $1=2=3=4=5$ \\
\hline 6 hours & $2.7(0.4)$ & $1.9(0.2)$ & $2.2(0.2)$ & $1.5(0.5)$ & $2.6(0.2)$ & 2.277 & 0.064 & $1,5>4>2,3$ \\
\hline 12 hours & $2.8(0.5)$ & $2.4(0.3)$ & $4.5(1.9)$ & $0.8(0.3)$ & $2.6(0.2)$ & 8.605 & $<0.001$ & $3>1,2,5>4$ \\
\hline \multicolumn{9}{|l|}{ RSS } \\
\hline 1 hour & $2.2(0.8)$ & $2.5(0.9)$ & $3.0(1.1)$ & $2.4(1.0)$ & $2.5(0.9)$ & 3.168 & 0.016 & $3>1,2,4,5$ \\
\hline 2 hours & $2.1(0.6)$ & $2.1(1.0)$ & $2.2(1.0)$ & $2.2(0.8)$ & $2.1(0.8)$ & 0.106 & 0.980 & $1=2=3=4=5$ \\
\hline 4 hours & $2.0(0.7)$ & $2.2(0.8)$ & $2.1(1.0)$ & $2.1(1.0)$ & $1.8(0.9)$ & 0.829 & 0.509 & $1=2=3=4=5$ \\
\hline 6 hours & $2.2(0.5)$ & $2.2(0.6)$ & $2.2(0.6)$ & $2.3(0.5)$ & $2.1(0.6)$ & 0.381 & 0.822 & $1=2=3=4=5$ \\
\hline 12 hours & $2.1(0.4)$ & $2.2(0.6)$ & $2.0(0.8)$ & $2.1(0.5)$ & $2.1(0.6)$ & 0.311 & 0.871 & $1=2=3=4=5$ \\
\hline
\end{tabular}

$S D=$ Standard Deviation; OASS = Overt Agitation Severity Scale; OAS = Overt Agitation Scale; RSS = Ramsay Sedation Scale.

emergency room settings due to the rapid onset of its effects and the ability to administer it to uncooperative patients. ${ }^{26}$ However, this approach is associated with several potential drawbacks. Benzodiazepines have the potential to cause respiratory depression, usually midazolam more so than lorazepam. Thus, the use of this group of drugs outside of services fully qualified in observing for and managing the consequences of respiratory distress is difficult to justify. ${ }^{4,24}$ Many patients perceive parenteral administration as coercive and abusive, and $93 \%$ of patients rank oral formulations as their preferred treatment option during a behavioral emergency. ${ }^{15}$

Midazolam's half-life is two to three hours with a duration of action generally up to 120 minutes. Some adverse effects are associated with the IM use of midazolam, including amnesia, respiratory depression, paradoxical reactions and confusion. ${ }^{23}$ Although many physicians in Brazil use haloperidol plus midazolam for agitated patients, before this study, there was no research on the efficacy and safety of this combination. In this study, we had the worst results with the haloperidol plus midazolam groups. The mean ratios for agitation and aggressive behavior within twelve hours were higher, and this group had a higher need for mechanical restriction, excessive sedation and additional medication. This combination also resulted in a greater number of patients who still were not fully tranquilized after twelve hours. We believe that the poor results of haloperidol plus midazolam were due to two factors: its short halflife and the paradoxical reaction of midazolam. This last reaction was observed in previous reports ${ }^{27-30}$ and may have been exacerbated by the anticholinergic effects of promethazine (haloperidol plus promethazine was the standard option for additional medication in this study).
One possible alternative to midazolam is lorazepam, which is effective for rapid tranquilization. ${ }^{24}$ Its association with haloperidol was safe but had conflicting results when compared with the use of lorazepam alone. ${ }^{18,21,31}$ In addition, intramuscular lorazepam is not available in Brazil.

Atypical antipsychotic agents are a newer class of drugs that are gaining popularity in the treatment of acutely agitated patients because of their more favorable side effects. Atypical antipsychotics are as effective as typical antipsychotics and have reduced the incidence of extrapyramidal side effects, including akathisia, dystonia and tardive dyskinesia. ${ }^{17,32}$ Of the atypical agents, two currently have an IM form available: olanzapine (Zyprexa®) and ziprasidone (Geodon $\left.{ }^{\circledR}\right)$. Both are at least as effective as haloperidol at producing rapid tranquilization in acutely agitated patients. Peak plasma concentrations of ziprasidone are achieved within 30 to 45 minutes with a half-life of 2.2 to 3.4 hours after IM injection. Similar results were obtained after IM injection of olanzapine with a peak plasma concentration achieved within 15 to 30 minutes. Atypical antipsychotics may be associated with prolongation of the QT interval and sudden cardiac death, and appropriate precautions should be taken when administering the drug. ${ }^{17,33}$

Although some trials have provided limited evidence for a superior speed of onset ${ }^{34,35}$ or degree of response, ${ }^{32,34,36}$ other studies have demonstrated similar results between first-generation and second-generation antipsychotics (SGA). ${ }^{10,37}$ Moreover, other studies have not consistently demonstrated the superior efficacy of SGA compared to haloperidol alone. ${ }^{35,38-40}$ Our results demonstrated that olanzapine required fewer additional medications, which was different from the results of the TREC 
study. ${ }^{4}$ Some clinical trials among patients with acute agitation associated with schizophrenia have demonstrated that the IM formulations of atypical antipsychotics provide similar efficacy to those of conventional antipsychotics, albeit without the associated high incidence of extra-pyramidal side effects (EPS). ${ }^{14,37,41-43}$

Short-term treatment with atypical antipsychotics offers improvements over haloperidol. In a seven-day randomized, open-label multicenter international study, the efficacy of IM ziprasidone (10mg initially, then 5 to $20 \mathrm{mg}$ every 4 to 6 hours, up to a maximum daily dose of $80 \mathrm{mg} ; \mathrm{n}=90$ ) was compared with that of IM haloperidol (2.5 to $10 \mathrm{mg}$, up to a maximum daily dose of $40 \mathrm{mg} ; \mathrm{n}=42$ ) in the treatment of hospitalized patients with acute psychotic agitation. ${ }^{9}$ Treatment with IM ziprasidone achieved significantly greater mean reductions from the baseline in psychotic symptoms and agitation compared with IM haloperidol. Furthermore, the mean percentage improvement in efficacy variables with IM ziprasidone was at least double that of IM haloperidol. Adverse events, and especially EPS, were reported less frequently with IM ziprasidone than with IM haloperidol. ${ }^{9}$ In a similar short-term study, IM olanzapine was associated with significant reductions in agitation 15 minutes, 30 minutes and 45 minutes after the first injection, as compared to
IM haloperidol. This result indicates a more rapid onset of action. In this and two other short-term studies, ${ }^{34}$ IM olanzapine and IM haloperidol showed similar efficacy from two hours after the first injection. Another study demonstrated that olanzapine had similar proportions of people being tranquil or asleep at 15 minutes than haloperidol plus promethazine; however, contrary to our results, more people given olanzapine required additional drugs over four hours than those given haloperidol plus promethazine. ${ }^{10}$

In settings where medical resources are scarce or clinics are busy, the longer duration of action for olanzapine, ziprasidone, haloperidol plus promethazine and haloperidol alone exposes people to dangerous behavior for shorter periods of time, provides fewer occasions for doctors to be called in and results in a reduced need for additional drugs over the first few hours. In addition, the cost of drugs poses one of the biggest problems for these interventions. Haloperidol and promethazine are both on the World Health Organization's list of essential drugs. ${ }^{4}$ In combination, these drugs cost nearly a third less than injectable olanzapine. If the costs of the additional drugs used and the utilization of additional resources were totaled, the difference is likely to favor haloperidol plus promethazine or haloperidol alone.

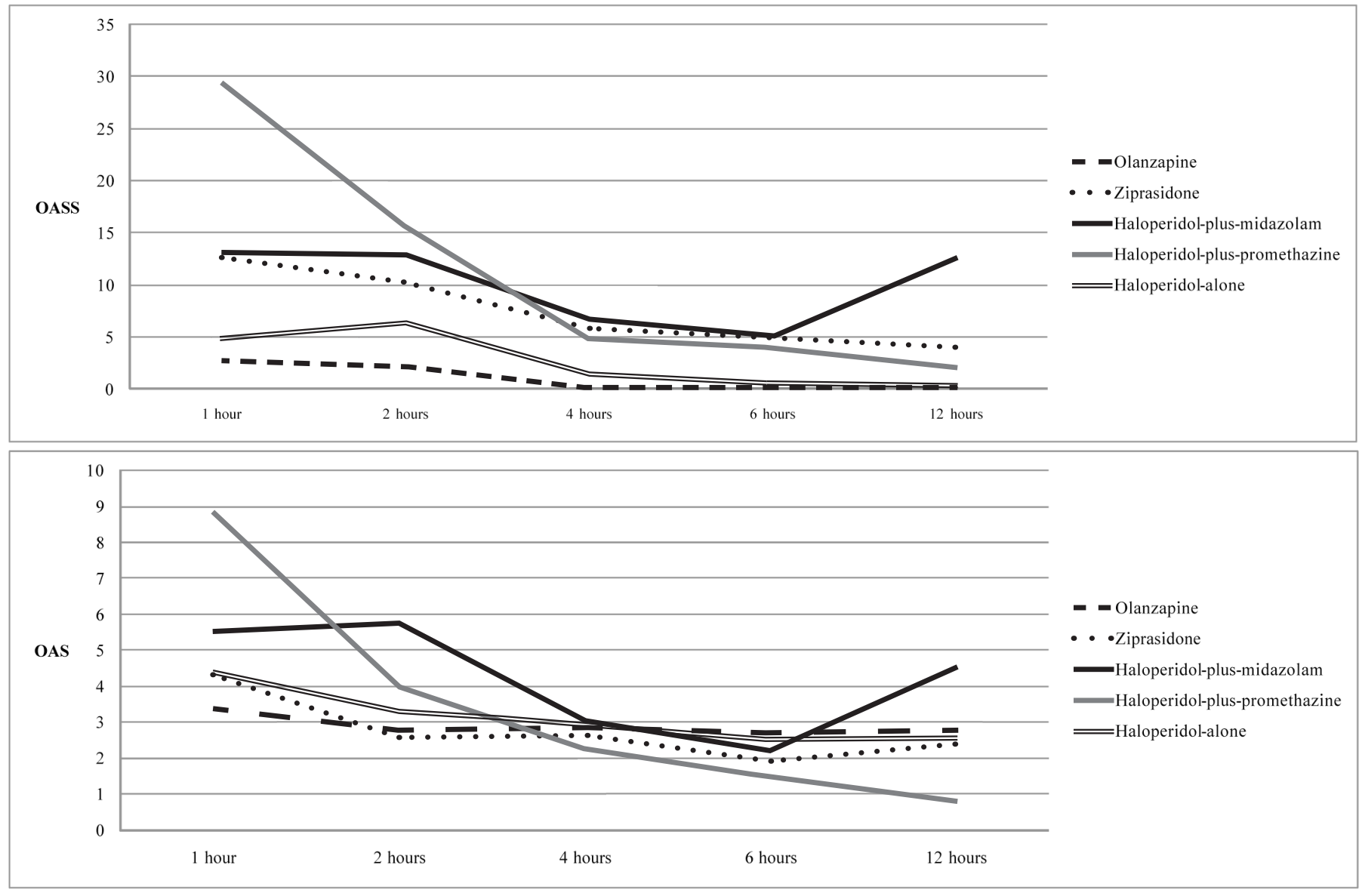

OASS: Overt Agitation Severity Scale; OAS: Overt Agression Scale.

Figure 2 - Changes in OASS and OAS during the study 
Table 3 - Means ratios, mean of all ratios and number of patients with OASS and OAS low scores after 12 hours

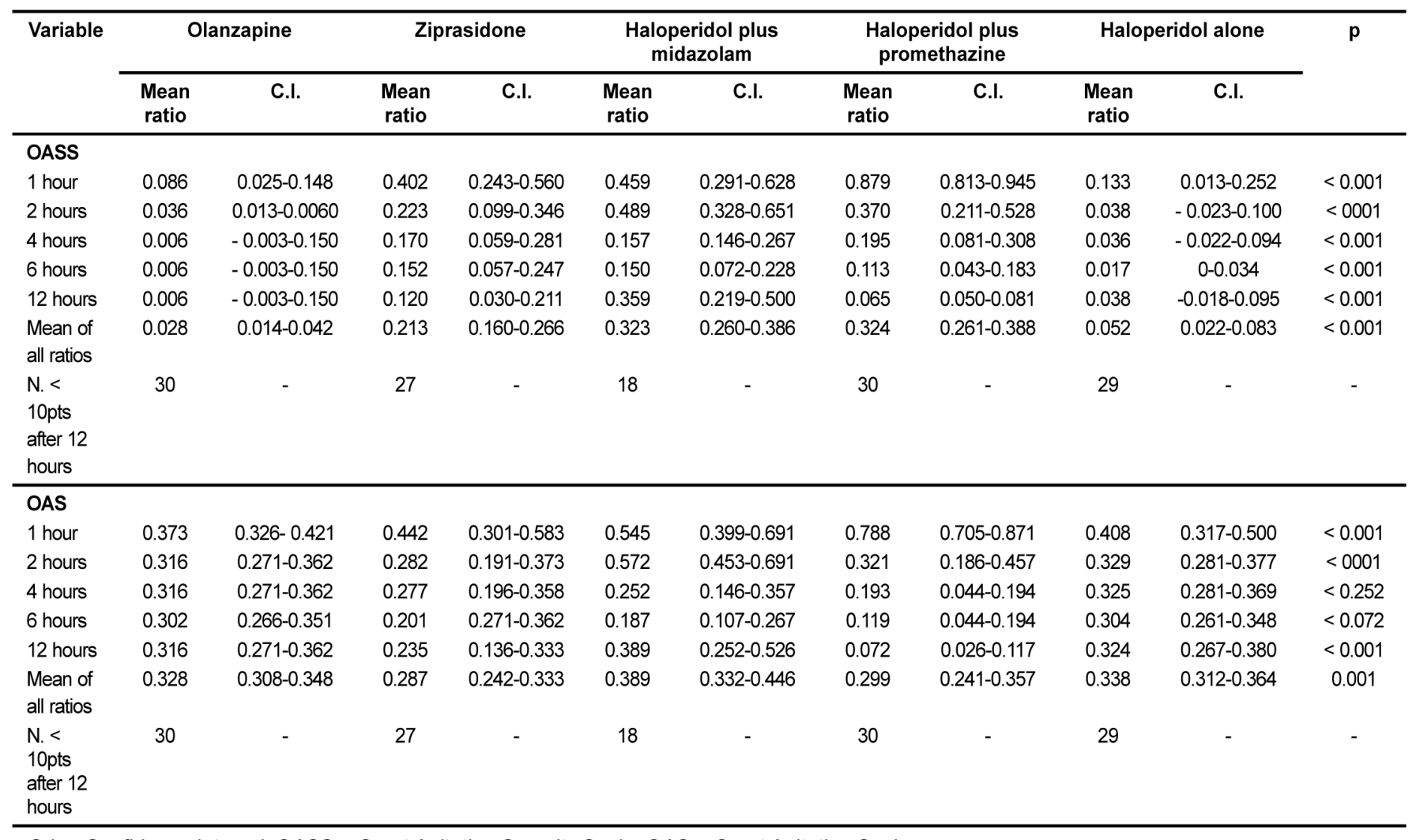

C.I. = Confidence Interval; OASS = Overt Agitation Severity Scale; OAS = Overt Agitation Scale

\section{Limitations}

The present study suffers from a number of limitations that must be taken into account in the interpretation and generalization of these results. First, the setting was a psychiatric emergency service of a large metropolitan area. This means that psychiatrists in the emergency room are often under pressure and at high risk of excessively rapid evaluations and dispositions. We tried to minimize this factor by using the inter-rater reliability of the raters. Second, we only included in the study patients who gave informed consent to exclude those who were more severely ill and who were compulsorily admitted. This is not an unusual problem in clinical research, but it is one that could impair the generalizability of the results. Third, our sample size may not have been large enough to detect small differences, but our objective was to compare several options of rapid tranquilization used by physicians in Brazil. Fourth, we evaluated only patients with psychotic or manic episodes because another diagnosis could require the adjustment of the drug regimen, such as intoxication, delirium and dementia.

Moreover, there are potential limitations of OASS and OAS. OASS and OAS evaluate only agitation and aggression conditions. They are not diagnosis scales and are not appropriate for observing psychotic or mood symptoms. However, they are indicated for acute situations. In addition, these scales require training and inter-rater reliability because they can be easily exaggerated or minimized by the person completing them. Like all questionnaires, the method by which the instrument is administered can have an effect on the final score. Finally, RSS relies on patient auditory and visual acuity and is not suitable for patients with severe impairments.

\section{Conclusion}

Olanzapine, ziprasidone, haloperidol plus promethazine, haloperidol plus midazolam and haloperidol alone were effective in controlling agitation and violent behavior resulting from mental illness by producing tranquilization over 12 hours. Patients given olanzapine had better results for agitation control, a lower percentage of excessive sedation and less need of mechanical restriction. Patients given ziprasidone had better results for controlling aggressive behavior, followed by haloperidol plus promethazine. All the drug combinations had advantages and disadvantages, and the combination of haloperidol plus midazolam showed the worst results in all the parameters observed. Aside from their higher cost, atypical antipsychotics may be helpful and might be an option in emergencies. 
Disclosures

\begin{tabular}{|c|c|c|c|c|c|c|c|}
\hline $\begin{array}{l}\text { Writing group } \\
\text { member }\end{array}$ & Employment & $\begin{array}{l}\text { Research } \\
\text { grant }^{1}\end{array}$ & $\begin{array}{l}\text { Other research } \\
\text { grant or medical } \\
\text { continuous } \\
\text { education }{ }^{2}\end{array}$ & $\begin{array}{l}\text { Speaker's } \\
\text { honoraria }\end{array}$ & $\begin{array}{c}\text { Ownership } \\
\text { interest }\end{array}$ & $\begin{array}{l}\text { Consultant/ } \\
\text { Advisory } \\
\text { board }\end{array}$ & Other ${ }^{3}$ \\
\hline $\begin{array}{l}\text { Leonardo } \\
\text { Baldaçara }\end{array}$ & $\begin{array}{l}\text { UFT }^{* *} \\
\text { Secretaria de } \\
\text { Estado da } \\
\text { Saúde do } \\
\text { Tocantins }^{* *}\end{array}$ & $\begin{array}{l}\text { FAPESP }^{\star \star * *} \\
\text { CNPq }^{* \star *}\end{array}$ & - & - & - & - & $\begin{array}{c}\text { AstraZeneca* } \\
\text { Jansen- } \\
\text { Cilag* } \\
\text { Libbs* }^{*}\end{array}$ \\
\hline Marsal Sanches & $\begin{array}{c}\text { University of } \\
\text { Texas }\end{array}$ & $\mathrm{NIH}^{*}$ & - & - & - & - & AstraZeneca* \\
\hline $\begin{array}{l}\text { Daniel Cruz } \\
\text { Cordeiro }\end{array}$ & - & - & - & - & - & - & - \\
\hline $\begin{array}{l}\text { Andrea Parolin } \\
\text { Jackoswski }\end{array}$ & UNIFESP* & $\begin{array}{l}\text { FAPESP }^{\star \star * *} \\
\text { CNPq }^{\star * *}\end{array}$ & - & - & - & - & - \\
\hline
\end{tabular}

* Modest

** Significant

*** Significant: Amounts given to the author's institution or to a colleague for research in which the author has participation, not directly to the author.

Note: UFT = Universidade Federal de Tocantins; UNIFESP = Universidade Federal de São Paulo; FAPESP = Fundação de Amparo à Pesquisa do Estado de São Paulo; $\mathrm{CNPq}=$ Conselho Nacional de Desenvolvimento Científico e Tecnológico. NIH = National Institutes of Health .

For more information, see Instructions for Authors.

\section{References}

1. Expert Consensus Guideline Group. Treatment of schizophrenia 1999. The expert consensus guideline series. J Clin Psychiatry. 1999;60(Suppl 11):3-80.

2. TREC. Rapid tranquillisation for agitated patients in emergency psychiatric rooms: a randomised trial of midazolam versus haloperidol plus promethazine. BMJ. 2003;327(27):1-6.

3. Cunnane JG. Drug management of disturbed behaviour by psychiatrists. Psychiatr Bull. 1994;18:138-9.

4. Huf G, Coutinho ES, Adams CE. Haloperidol plus promethazine for agitated patients--a systematic review. Rev Bras Psiquiatr. 2009;31(3):265-70.

5. McAllister-Williams RH, Ferrier IN. Rapid tranquillisation: time for a reappraisal of options for parenteral therapy. Br J Psychiatry. 2002;180:485-9.

6. Allen $\mathrm{MH}$, Currier GW. Use of restraints and pharmacotherapy in academic psychiatric emergency services. Gen Hosp Psychiatry. 2004;26(1):42-9.

7. Chouinard G, Safadi G, Beauclair L. A double-blind controlled study of intramuscular zuclopenthixol acetate and liquid oral haloperidol in the treatment of schizophrenic patients with acute exacerbation. J Clin Psychopharmacol. 1994;14(6):377-84.

8. Jones B, Taylor CC, Meehan K. The efficacy of a rapid-acting intramuscular formulation of olanzapine for positive symptoms. J Clin Psychiatry. 2001;62 Suppl 2:22-4.

9. Brook S, Lucey JV, Gunn KP. Intramuscular ziprasidone compared with intramuscular haloperidol in the treatment of acute psychosis. Ziprasidone I.M. Study Group. J Clin Psychiatry. 2000;61(12):933-41.

10. Raveendran NS, Tharyan P, Alexander J, Adams CE. Rapid tranquillisation in psychiatric emergency settings in India: pragmatic randomised controlled trial of intramuscular olanzapine versus intramuscular haloperidol plus promethazine. BMJ. 2007;335(7625):865.

11. Huf G, Coutinho ES, Adams CE. Rapid tranquillisation in psychiatric emergency settings in Brazil: pragmatic randomised controlled trial of intramuscular haloperidol versus intramuscular haloperidol plus promethazine. BMJ. 2007;335(7625):869.

12. Jangro WC, Preval H, Southard R, Klotz SG, Francis A. Conventional intramuscular sedatives versus ziprasidone for severe agitation in adolescents: case-control study. Child Adolesc Psychiatry Ment Health. 2009;3(1):9.

13. SPSS Inc. SPSS for Windows. Chicago; 1989-2004.

14. Allen MH, Currier GW, Carpenter D, Ross RW, Docherty JP. The expert consensus guideline series. Treatment of behavioral emergencies 2005. J Psychiatr Pract. 2005;11 Suppl 1:5-108; quiz 10-2.

15. Allen MH, Currier GW, Hughes DH, Docherty JP, Carpenter D, Ross R. Treatment of behavioral emergencies: a summary of the expert consensus guidelines. J Psychiatr Pract. 2003;9(1):16-38.
16. Currier GW, Allen MH, Bunney EB, Daniel DG, Francis A, Jagoda A, Zimbroff D. Intramuscular antipsychotics: clinical experience review. J Emerg Med. 2004;27(4 Suppl):S3-4; quiz S8.

17. Marco CA, Vaughan J. Emergency management of agitation in schizophrenia. Am J Emerg Med. 2005;23(6):767-76.

18. Battaglia J, Moss S, Rush J, Kang J, Mendoza RLeedom L, Dubin W, McGlynn C, Goodman L. Haloperidol, lorazepam, or both for psychotic agitation? A multicenter, prospective, double-blind, emergency department study. Am J Emerg Med. 1997;15(4):335-40.

19. Mantovani C, Migon M, Alheira F, Del-Ben C. Management of the violent or agitated patient. Rev Bras Psiquiatr. 2010;32(Supl 2):96-103.

20. Garza-Trevino ES, Hollister LE, Overall JE, Alexander WF. Efficacy of combinations of intramuscular antipsychotics and sedative-hypnotics for control of psychotic agitation. Am Journal Psychiatry. 1989;146(12):1598601.

21. Bieniek SA, Ownby RL, Penalver A, Dominguez RA. A double-blind study of lorazepam versus the combination of haloperidol and lorazepam in managing agitation. Pharmacotherapy. 1998;18(1):57-62.

22. Huf G, Alexander J, Allen MH, Raveendran NS. Haloperidol plus promethazine for psychosis-induced aggression. Cochrane Database Syst Rev. 2009(3):CD005146.

23. Huf G, Coutinho ES, Adams CE; TREC-Rio trial. TREC-Rio trial: a randomised controlled trial for rapid tranquillisation for agitated patients in emergency psychiatric rooms [ISRCTN44153243]. BMC Psychiatry. 2002;2:11

24. Huf G, Alexander J, Allen MH. Haloperidol plus promethazine for psychosis induced aggression. Cochrane Database Syst Rev. 2005(1):CD005146.

25. Alexander J, Tharyan P, Adams C, John T, Mol C, Philip J. Rapid tranquillisation of violent or agitated patients in a psychiatric emergency setting. Pragmatic randomised trial of intramuscular lorazepam v. haloperidol plus promethazine. Br J Psychiatry. 2004;185:63-9.

26. Alderfer BS, Allen MH. Treatment of agitation in bipolar disorder across the life cycle. J Clinical Psychiatry. 2003;64 (Suppl 4):3-9.

27. Thurston TA, Williams CG, Foshee SL. Reversal of a paradoxical reaction to midazolam with flumazenil. Anesth Analg. 1996;83(1):192.

28. Honan VJ. Paradoxical reaction to midazolam and control with flumazenil. Gastroint Endosc. 1994;40(1):86-8.

29. Martinez-Telleria A, Cano ME, Carlos R. Paradoxical reaction to midazolam after its use as a sedative in regional anesthesia. Revista Espanola de Anestesiologia y Reanimacion. 1992;39(6):379-80.

30. Short TG, Forrest P, Galletly DC. Paradoxical reactions to benzodiazepines-a genetically determined phenomenon? Anaesth Intensive Care. 1987;15(3):330-1. 
31. Veser FH, Veser BD, McMullan JT, Zealberg J, Currier GW. Risperidone versus haloperidol, in combination with lorazepam, in the treatment of acute agitation and psychosis: a pilot, randomized, double-blind, placebo-controlled trial. J Psychiatr Pract. 2006;12(2):103-8.

32. Oliveira IR, Nunes PM, Coutinho DM, Sena EP. Review of the efficacy of placebo in comparative clinical trials between typical and atypical antipsychotics. Rev Bras Psiquiatr. 2008;31(1):52-6.

33. Ray WA, Chung CP, Murray KT, Hall K, Stein CM. Atypical antipsychotic drugs and the risk of sudden cardiac death. NEngJ Med. 2009;360(3):225-35.

34. Wright P, Birkett M, David SR, Meehan K, Ferchland I, Alaka KJ, Saunders JC, Krueger J, Bradley P, San L, Bernardo M, Reinstein M, Breier A. Doubleblind, placebo-controlled comparison of intramuscular olanzapine and intramuscular haloperidol in the treatment of acute agitation in schizophrenia. Am J Psychiatry. 2001;158(7):1149-51.

35. Satterthwaite TD, Wolf DH, Rosenheck RA, Gur RE, Caroff SN. A metaanalysis of the risk of acute extrapyramidal symptoms with intramuscular antipsychotics for the treatment of agitation. J Clin Psychiatry. 2008;69(12):1869-79.

36. Brook S, Walden J, Benattia I, Siu CO, Romano SJ. Ziprasidone and haloperidol in the treatment of acute exacerbation of schizophrenia and schizoaffective disorder: comparison of intramuscular and oral formulations in a 6-week, randomized, blinded-assessment study. Psychopharmacology (Berl). 2005;178(4):514-23.

37. Battaglia J. Pharmacological management of acute agitation. Drugs. 2005;65(9):1207-22.

38. Andrezina R, Josiassen RC, Marcus RN, Oren DA, Manos G, Stock E, Carson WH, Iwamoto T. Intramuscular aripiprazole for the treatment of acute agitation in patients with schizophrenia or schizoaffective disorder: a double-blind, placebo-controlled comparison with intramuscular haloperidol. Psychopharmacology (Berl). 2006;188(3):281-92.

39. Breier A, Meehan K, Birkett M, David S, Ferchland I, Sutton V, Taylor CC, Palmer R, Dossenbach M, Kiesler G, Brook S, Wright P. A doubleblind, placebo-controlled dose-response comparison of intramuscular olanzapine and haloperidol in the treatment of acute agitation in schizophrenia. Arch Gen Psychiatry. 2002;59(5):441-8.

40. Daniel DG, Zimbroff DL, Swift RH, Harrigan EP. The tolerability of intramuscular ziprasidone and haloperidol treatment and the transition to oral therapy. Int Clin Psychopharmacol. 2004;19(1):9-15.

41. Altamura AC, Sassella F, Santini A, Montresor C, Fumagalli S, Mundo E. Intramuscular preparations of antipsychotics: uses and relevance in clinical practice. Drugs. 2003;63(5):493-512.

42. Damsa C, Adam E, Lazignac C, De Gregorio F, Mihai A, Lejeune J, Sarasin F, Allen MH. Intramuscular olanzapine in patients with schizophrenia: an observational study in an emergency room. Bull Soc Sci Med GrandDuche Luxemb. 2008(2):209-16.

43. Brook S. Intramuscular ziprasidone: moving beyond the conventional in the treatment of acute agitation in schizophrenia. J Clin Psychiatry. 2003;64(Suppl 19):13-8. 